\title{
Świat frantów i sowizdrzalów w wybranych utworach literatury dawnej
}

Marzena Wydrych-Gawrylak 
nAPクS Seria XIV 2008

\author{
Marzena Wydrych-Gawrylak
}

\title{
Świat frantów i sowizdrzałów w wybranych utworach literatury dawnej
}

Tmię Sowizdrzała powszechnie kojarzone jest z nurtem „literatury sowizdrzalskiej”, którym to mianem określa się twórczość plebejskich, bezimiennych humorystów końca XVI i pierwszej połowy XVII wieku, tworzącą w piśmiennictwie staropolskim nurt opozycyjny wobec literatury warstw uprzywilejowanych, prowokacyjnie ośmieszającą mity i ideały kultury „oficjalnej”, zarówno szlachecko-kościelnej, jak mieszczańskiej, parodiującą pojęcia etyczne i estetyczne, deprecjonującą świat wartości społecznych, politycznych, moralnych i konwencji obyczajowych w tej kulturze obowiązujących. Pozytywnym wzorom i nakazom, utrwalonym przez renesansową literaturę parenetyczną i panegiryki, literackim pochwałom feudalnych bohaterów (rycerzy, wodzów), feudalnego porządku świata i wzoru życia przeciwstawiała literatura sowizdrzalska błazeńską karykaturę, groteskową negację i absurdalny wizerunek świata "na wywrót" czy „na opak"1.

Frant zaś to postać ze staroczeskiej humoreski o zacięciu satyrycznym, przełożonej na język polski około roku 1530 (dziś zachowały się tylko fragmenty), a zawierającej zabawną parodię ustaw cechowych, spisanych dla nierobów i wesołych hulaków rzekomo przez pilzneńskiego lekarza Johannesa Frantę (skądinąd postać autentyczną)2.

Miano "Sowizdrzal” stało się niejako ideologiczną wizytówką literacką zarówno dzieł, jak i ich autorów, ale nie jest to jego jedyny sposób funkcjonowania. Obok bowiem imienia własnego zaczęto też stosować jego formę przymiotnikową „sowizdrzal-

${ }^{1}$ Zob. S. Grzeszczuk, Sowizdrzat, w: Literatura polska. Przewodnik encyklopedyczny, t. 2, Warszawa 1985, s. 388.

${ }^{2}$ Zob. J. Krzyżanowski, Frant, w: ibidem, t. 1, Warszawa 1984, s. 275. 
ski”, która funkcjonuje wymiennie z przymiotnikiem „frantowski”. Przy czym, jak stwierdza Stanisław Grzeszczuk, ze względu na mniejsze rozpowszechnienie imienia „Franta” łatwiej było nie tylko używać go w formie przymiotnikowej, ale też przetworzyć je na rzeczownik pospolity i stosować wymiennie z określeniami: „figlarz”, „lgarz”, „błazen”, „dobry towarzysz”, a niestroniących od trunku i wesołej zabawy dobrych kompanów zwykło się określać mianem „frantowskiego cechu”. Wyraz „frant” — semantyczny odpowiednik "sowiźrzała” - występuje w ówczesnym języku wcale często, podczas gdy „sowiźrzal” jako wyraz pospolity rozpowszechnił się później.

Jak wolno przypuszczać na podstawie lektury dzieł literatury dawnej, określenie "frantowski” szybko stało się w świadomości literatów staropolskich jakością autonomiczną i oderwało od imienia wlasnego, a „frantostwo" stało się synonimem pewnego, określonego zbioru cech (frywolność skojarzeń, przytomność umysłu, cięty język, spryt, skłonność do śmiechu, drwin i zabawy cudzym kosztem, zdystansowany stosunek do rzeczywistości).

Frant to ten, kto chce kogoś odrwić i odrwi, jeśli tylko nadarzy się okazja, ale i ten, który odrwić się innym nie pozwala, a zmuszony do reakcji, broniąc swej godności (czy ratując twarz), potrafi zareagować na zaczepkę celną ripostą, umie wykręcić się z kłopotów ciętą odpowiedzią, wytrącając „oręż” z ręki strony przeciwnej, ale też dowcipnym komentarzem przydaje rzeczywistości smaku (a czasem wręcz „pieprzu”).

Jak przekonuje lektura tekstów, frantowie zaludniają nie tylko karty na pół oficjalnej literatury sowizdrzalskiej i przynależą do "dobrego cechu”, ale z powodzeniem goszczą we fraszkach czy dziełach dramatycznych wielu autorów, wnosząc do nich swoisty humor i specyficzny sposób wypowiadania się — styl „frantowskiej odpowiedzi”.

I to właśnie „frantostwo” jako zespół cech, a także owa stylistyka będą przedmiotem niniejszych rozważań.

W Figlikach pana Rejowych frantostwo jest dość powszechne i wydaje się rozumiane przede wszystkim jako spryt. I tak na przykład w figliku Co sędziemu kamień ukazowat4 przekupny urzędnik państwowy został odrwiony przez petenta-franta, który w czasie rozprawy wskazywał na coś, co mial schowane w zanadrzu, a co sędzia potraktował jako zapowiedź „podarunku”, toteż po „odsądzeniu” na korzyść owego petenta podszedł doń, by otrzymać zapłatę. Zawiódl się jednak srodze, bo zamiast daru ujrzał kamień i usłyszal, że „tym pamiętnym w czoło” miał być „poczęstowany” gdyby wyrok okazal się niesprawiedliwy. Nietypowy to figlik, gdyż częściej u Reja spryciarzami okazują się urzędnicy, jak ów sędzia ${ }^{5}$, który wziąwszy od jednego klienta „dwa kapłony tłuste" wydaje jednak wyrok nie po jego myśli, lecz na korzyść innego, który przyniósł

${ }^{3}$ Zob. S. Grzeszczuk, Nazewnictwo souiźrzalskie, Kraków 1966, s. 34-35.

${ }^{4}$ Zob. M. Rej, Figliki, opr. M. Bokszczanin, wst. J. Krzyżanowski, Warszawa 1974, s. 46.

${ }^{5}$ Zob. idem, Co dat lisa sędziemu, ibidem. 
dar bardziej wartościowy — lisa. Składający reklamację — były właściciel kapłonów — słyszy, że „kury” zostały zjedzone przez lisa, który przybiegł spod miasta, i... musi odejść z niczym, a sędzia korzysta z naiwności obu klientów ${ }^{6}$.

Frantowską odpowiedź usłyszał też pan jadący drogą, przy której za dębem chłop załatwiał potrzebę („srał”), a widząc przejeżdżającego, zaczął się „gubać” (podkasywać, ubierać). Podróżny, chcąc okazać wielkopańską laskawość, mówiąc: „Siedź nieboże! / Bo wiem, że sie bez tego nikt obejć nie może" - naraził się na niewybredną, ale ze zdrowego rozsądku wynikającą chłopską (frantowską) odpowiedź:

"Ja sie bez tego, panie obejć mogę

I tak, to zostawiwszy przed się pójdę w drogę.

Wy, chcecie li, weźmicie, mnie tego nie trzeba,

$\mathrm{Na}$ to miejsce wolałbych juz kawalec chleba"”.

W tym przypadku chlop — „prostak” poczuł się sprowokowany do odpowiedzi sytuacją. Łaskawe słowa potraktował jak zaczepkę i udowodnil, że niektóre, zwlaszcza niezręczne, sytuacje nie powinny być przedmiotem oglądu, a już z całą pewnością nie należy ich głośno komentować, bo przydając innym wstydu, samemu można się narazić na śmieszność.

Dowcipnym frantem okazał się też Polak w podróży włoskiej. Gdy zobaczył swego kucharza powieszonego przy drodze, skomentował rzecz całą ze stoickim spokojem:

„Wierę, pan Matusz nasz to wisieć raczy!

Wej, przedsię naszy górą, chociaj w cudzej ziemi.

Ale my tę gospodę, co zjednal, miniemy"

Opowiastka ta znalazła swoją kontynuację u Wacława Potockiego, gdzie w epigramacie Humor polski $i^{9}$ bohaterem anegdoty stał się pan Rej (prawdopodobnie Andrzej, wnuk Mikolaja, poseł do Anglii w 1637 r. $)^{10}$. U Potockiego jednak pointa jest krótsza i bardziej w stylu frantowskim utrzymana - Rej, widząc "przysądzonego drzewu” (powieszonego) Polaka,

Uchyliwszy firanka, wesołą posturą

Rzecze do swych z karety: „Przecię naszy górą!”.

Frantostwo - spryt nie przynależy wyłącznie mężczyznom, wiele jest też kobiet, które nie zapominają, po co mają rozum i język, a często bywają od mężczyzn sprytniejsze.

\footnotetext{
${ }^{6}$ Podobnie w figliku: O sędziem, co wziqł wóz i konie (zob. ibidem, s. 156).

7 Idem, Chtop, co srat za dębem, ibidem, s. 120.

${ }^{8}$ Idem, Polakowi kucharza obiesili, ibidem, s. 127.

9 Zob. W. Potocki, Wiersze uybrane, opr. S. Grzeszczuk, wst. J. S. Gruchała, Wroclaw 1992, s. 200.

${ }^{10}$ Zob. ibidem, przyp. s. 200.
} 
W Pokucie żony z mę̇̇em Mikołaja Reja kobieta umie pomysłowo „wyłgać się” z kłopotu. Za pokutę ma mężowi powiedzieć prawdę o nie do końca wspólnym potomku. By wilk był syty i owca cała, czyli by pokutę odprawić, ale i nie narazić się na nieprzyjemności małżeńskie, każe mężowi włożyć maskę na twarz i dla zabawy dziecko postraszyć, sama zaś spełnia pokutę, gdy porwawszy dziecię w ramiona, uciekając, niby żartem woła: „Wierę, panie stary, / Nie twojeć, daj mu pokój!”11.

Inna z żon, w epigramacie Respons niespodziewany ${ }^{12}$ Daniela Naborowskiego, jest odważniejsza - mężowskie fukania na „rogacze” pointuje bardzo czytelnie, acz z sowizdrzalskim wdziękiem:

„Topić - mówił małżonek — rogacze potrzeba".

Żona na to: „Uczyć się, miły, pływać trzeba”.

$\dot{Z}$ e „chytry jad niewiasta”, udowadnia też kolejny figlik Reja: Dziewka, co czerwone nogi miata.

Dziewka prała na lodu, więc czerwone nogi

Ujźrzał jeden. Rzekł jej: — „Tu ogień w rzyci srogi”.

Powiedziała: — „Jest, panie! Małpa by się wściekła”.

On jej prosil, aby mu kiełbaskę upiekla.

Rzekła: — „Mnieć, panie, trudno, ale już tam w kuchni

Najdziesz ogień gotowy, jedno mocno dmuchni!".

Dobrze tak na zuchwalca, a co mu do tego,

Iż miał być szacunkarzem ogona cudzego ${ }^{13}$.

Zaczepiona niewybrednie dziewczyna próbuje zbyć natręta, wdając się z nim jednocześnie we frywolną grę słowną („małpa” to nie tylko psotne zwierzę, trzymane ówcześnie po dworach dla rozrywki, ale też synonim kobiety sprzedajnej, wszetecznicy, dziewki ulicznej, ladacznicy); gdy ten nie daje za wygraną i posuwa się w wyrazistych aluzjach zbyt daleko, zostaje odrwiony, niewinnym z pozoru odesłaniem do kuchni, ale podtekst erotyczny jest i tu wyraźnie czytelny - dziewczyna odsyła go do chętniejszej („najdziesz ogień gotowy”) kucharki, uprzedzając lojalnie, że będzie się jednak musiał nieco natrudzić („mocno dmuchni”). Ostatni dwuwers podkreśla, że dostało się tu właśnie „zuchwalcowi”, zaczepiającemu dziewczynę, ale to ona z potyczki słownej wyszła zwycięsko, bo „przegadała” franta, nie dając się zawstydzić.

${ }^{11}$ M. Rej, Pokuta żony z mężem, w: idem, Figliki, op. cit., s. 128.

${ }_{12}$ Zob. D. Naborowski, Respons niespodziewany, w: I w odmianach czasu smak jest. Antologia polskiej poezji epoki baroku, opr. J. Sokołowska, Warszawa 1991, s. 126.

${ }^{13}$ M. Rej, Figliki, op. cit., s. 52. 
Podobną sytuację sportretował Jan Kochanowski we fraszce $O$ dobrym panie. Tym razem bosa dziewczyna pracuje w polu, a przejeżdżający pan radzi, by nie chodziła bez butów, „bo macierzyzna tak zwietrzeje rada”. Zaczepiona dziewka odcina się celnie:

„Easkawy Panie, nic jej to nie wadzi,

Chyba, żebyście pijali z niej radzi”"14.

Pańska aluzja do „macierzyzny” - „matczynego majątku” (tu w rozumieniu dwuznacznym) wywołała natychmiastową reakcję przytomnego, prostego umysłu, i ten, kto chcial sobie zażartować cudzym kosztem, musi odjechać jak niepyszny.

Takimi właśnie frantowskimi (sowizdrzalskimi) responsami często bywają konceptyczne pointy fraszek Jana Kochanowskiego. Tak jest na przykład we fraszce O Koźle ${ }^{15}$, w której pan Koziel, będący „pod dobrą datą” („piwszy do północy”), nie może trafić do domu „o swej mocy” i usiluje się „dopytać” drogi (czy raczej - doprosić pomocy w dojściu) u przechodnia. Nieznajomy, usłyszawszy nazwisko „Kozieł”, stwierdza: „Idźże spać do chlewa!”. Odesłanie pijanicy do chlewa ma tu podwójnie komiczny wydźwięk - nawiązuje do odzwierzęcego nazwiska: miejsce kozła-zwierzęcia jest w chlewie; ale też tam jest miejsce tych, którzy nie zachowują się i nie wyglądają po biesiadzie jak ludzie.

W sowizdrzalskim tonie utrzymana pointa zamyka fraszkę $O$ kapellanie ${ }^{16}$. Królowa, nie mogąc doczekać się mszy, każe szukać księdza, którego nie można znaleźć, bo - jak się okazuje - „pilnował dzbana” gdzieś poza domem. Gdy, mocno spóźniony, zjawia się w końcu „w czerwonym ornacie" (czyli z czerwonym po przepiciu nosem), zostaje przez monarchinię z przekąsem zgromiony wyniosłym: „Ksze mily, długo to sypiacie!”, lecz zamiast się usprawiedliwiać i przepraszać, nie tracąc kontenansu, w czym swój udział ma zapewne i trunek, którym się całą noc raczyl, ripostuje przytomnie: "Jeszczem ci się dziś nie kładł, co za długie spanie?”. Tym samym okazuje się, że frantem w pewnych okolicznościach może stać się i osoba duchowna, a frantostwo (sowizdrzalstwo) ujdzie na sucho, bo rozładuje napiętą atmosferę.

Nieco inaczej rzecz wygląda we fraszce Przymówka chtopska ${ }^{17}$, w której przymuszany do picia „włódarz" kilkakroć stara się grzecznie wymówić, dziękując panu za łaskawość, ale też i bojąc się, „by słówkiem nie wyleciał, co więc chmiel rad broi” (nawiązanie do antycznego in vino veritas dostosowane zostało tu do potrzeb chłopa pijącego piwo, ale z doświadczenia wiedzącego, że „po pijaku” trudniej zapanować nad językiem). Gdy pan, niezrażony, wciąż natarczywie domaga się nie tylko picia, ale i konwersacji

${ }^{14}$ J. Kochanowski, Fraszki, opr. J. Pelc, Wrocław 1991 (BN I 163), s. 18.

${ }^{15}$ Zob. ibidem, s. 56-57.

${ }^{16}$ Zob. ibidem, s. 58-59.

17 Zob. ibidem, s. 165. 
(„Pij ty, włódarzu, i mów, coć się będzie zdało, / Prosto, jako za naszych ojców więc bywało") chłop przytomnie, ale i stawiając się niejako w roli strażnika dobrych, dawnych obyczajów, dyplomatycznie, acz z frantowską odwagą stara się przywołać pana (zapewne też już niemało podpitego — stąd ta potrzeba szczerości i „bratanie się z ludem”) do porządku i stwierdza:

„Takci bywało, panie, pijaliśmy z sobą,

Ani gardził pan kmiotka swojego osobą;

Dziś wszytko już inaczej, wszytko spoważniało, Jako mówią, postawy dosyć, wątku mało".

Kolejnym autorem, w którego zbiorach fraszkowych odnaleźć możemy sporo tekstów, gdzie dowcip zasadza się właśnie na frantowskich odpowiedziach, jest wspomniany wyżej Wacław Potocki. W tekście Żartem się prawdy domówic ${ }^{18}$ mamy pana i chłopca-służącego, sportretowanych w sytuacji wieczornego odpoczynku. Nie mogąc zasnąć, pan nakazuje, by chłopiec bawil go opowieściami, aż mu „się jako sen naprawi”. Po dwóch godzinach zmęczonemu słudze („chłopiec by spał do zdechu”) zabrakło pomysłów, a panu wciąż mało. Na kolejny nakaz: „Prawże jeszcze!”, zdesperowany chłopiec, „chcąc wydrwić się co prędzej”, rzecze: „Nie mam koszule, czapki, trzeba mi pieniędzy”, czym rozbawia pana, który „rozśmiawszy się sam w sobie” wreszcie pozwala mu zasnąć („Idź spać, nie wybijaj mię ze snu, mój kochany!”).

Frantostwo „zdroworozsądkowe” prezentuje też chlop z Frantowskiej odpowiedzi:

„Pomaga Bóg! - potkawszy chłopa ze drwy rano, A co to wieziesz?” — rzekę. Odpowie mi: „Siano”. „Drwa-ć ja widzę, obiesiu, czemuż ze mnie szydzisz?” „Ba, ty ze mnie, pytając, co wiozę, choć widzisz”"19.

Pan, chcąc nawiązać kurtuazyjną rozmowę na powitanie, stawia nierozsądne pytanie, na które zdrowy chłopski rozum każe odpowiedzieć drwiną — na zasadzie: jakie pytanie (głupie), taka odpowiedź. Konwencja zostaje złamana, gdy pan wpada w złość, czując się dotknięty „szyderstwem” i arogancją chłopa, ten jednak niezbity z pantałyku odcina się, stwierdzając, że to najpierw on został wyszydzony, więc tylko starał się nie pozostać dłużny.

Podobny typ dowcipu funkcjonuje we fraszce Pijany a dziecię prawdẹ powie $e^{20}$. Podróżny, zatrzymawszy się w gospodzie, najmuje chłopca do posługi dla swej żony, dając mu konkretne zadanie: „Będzieszże — rzekę — ogon nosił mi za panią?”. Na co chłopczyk

\footnotetext{
${ }^{18}$ Zob. W. Potocki, Wiersze uybrane, op. cit., s. 185.

${ }^{19}$ Ibidem, s. 150.

${ }^{20}$ Zob. ibidem, s. 142.
} 
zdziwiony, z głupia frant („w skok”) stwierdza (a w zasadzie obrusza się): „Cóż dobrego mówicie! Alboż ona krowa?”, czym wywołuje oczywiście powszechną wesołość, ale nie to jest istotą tekstu. Fraszka, wykorzystująca komizm sytuacji i dwuznaczność słowa „ogon”, jest jednocześnie satyrycznym komentarzem do ówcześnie panującej mody, zwłaszcza damskiej, z której drwi autor niejednokrotnie, wytykając elegantkom muszki, bielenie i barwienie lic, peruki, trzęsidła itd. Tu dostało się „nieszczęśliwej pysze”, na którą i „wrony kraczą", a która nakazuje damom nosić suknie z „ogonami” czyli trenami.

Frantowski dowcip i u Potockiego bywa aluzyjnie obsceniczny, tak jak we fraszce Ptótno ${ }^{21}$, w której frant i „pani chlubna” szacują swoje majątki. Dowcip oparty tu został, jak to często u Potockiego bywa, na filologicznym i zarazem komicznym wyzyskaniu niejednoznaczności słowa „płótno”, które można było rozumieć jako „materiał”, ale też jako „spodnie” lub „bieliznę”:

Chwali się jedna pani chlubna, że istotnie

Dziesięć tysięcy złotych ma w bielonym płotnie.

„Mogę się ja — rzecze frant — szacować na więcej:

Nie dałbym, co mam w płótnie, i za sto tysięcy”.

Aluzyjny komentarz stanowi tu nie tyle frantowską odpowiedź na zaczepkę, ile drwinę z przechwałek o wartości tego, co się posiada. Dla kobiety istotna jest realna wartość materialna, która pozwala jej się czuć osobą bogatą, z czego frant drwi, niewiele zapewne majętności posiadając, woli za cenne uznawać inne walory — osobiste, nie są to jednak przymioty duchowe, lecz namacalnie fizyczna (namacalna fizycznie) „męska chluba”. Wniosek jest oczywisty: cenić wysoko trzeba przede wszystkim siebie (własne przymioty), bo to jedyna rzecz, jaką w istocie posiadamy.

Z fraszki Wet za wet ${ }^{22}$ wynika, iż celna, frantowska, inteligenta riposta bywa cenna i pożądana w różnych okolicznościach, a przydaje się też i na królewskich pokojach. Fraszka pochodzi (jak wszystkie już wzmiankowane) ze zbioru Ogród, ale nie plewio$n y$... i wyjątkowo doń pasuje, bo można by określić ją mianem owocowej. Przynosząc w darze królowi cytrynę - owoc egzotyczny, a więc drogi i rzadki, ofiarodawca prosi o starostwo Wiśnie (nadanie urzędu). Jest jednak jeden kłopot — starosta jeszcze żyje. Trzeba zatem skorzystać ze skarbnicy humoru, by petenta przywołać do porządku, jednocześnie dać nauczkę jemu i innym, a przy okazji docenić dar (cytrynę) i nie urazić zbytnio ofiarodawcy. Król więc nie w ciemię bity

Odpowie jak z proce:

„Barzo słuszna owocem nagradzać owoce.

${ }^{21}$ Zob. ibidem, s. 153.

22 Zob. ibidem, s. 208. 
Jednakże wiśnie nie masz, na ten czas się figą

Kontentujcie".

Cóż pozostało proszącemu o rzecz niemożliwą? - „Zrozumiał i poszedł za dygą”. Do pełnego obrazu sytuacji komicznej można by tu, jak sądzę, dołączyć jeszcze i frantowski gest ową figę ilustrujący - pytanie tylko, czy król móglby ten gest wykonać? $\mathrm{Z}$ całą pewnością jednak podkreśliłby on wyrazistość odmowy.

U Potockiego znajdziemy również i frantowskie prawa, a w zasadzie parodię praw, utrzymaną $\mathrm{w}$ stylu sowizdrzalskim. $\mathrm{W}$ jedynym $\mathrm{w}$ dorobku poety utworze dramatycznym - Dyjalogu o Zmartwychwstaniu Pańskim ${ }^{23}$ — „za gardło lańcuchem” przykuty w piekle diabel Gryga prezentuje prześmiewczy dekalog:

„Nie będziesz kradł,

Nie będziesz jadł;

Nie będziesz zbijal,

Nie będziesz pijal;

Nie będziesz cudzołożył,

Nie będziesz się mnożył;

Nie będziesz przysięgal krzywo,

Nic nie będziesz mial jak żywo;

Nie czcij ojca ani matki,

Wydrzesz im wszytkie dostatki;

Świeć gębą, choć broni serce,

Kwoli gorzałki kwaterce;

Nie święć święta i niedziele,

Nie bywaj nigdy w kościele.

$\mathrm{Nie}$ będziesz pragnął cudzego,

Pewnie nie pożyjesz swego".

Z taką „regułą” Gryga jest pewien, że „osiądzie” jakąś „prebendę” i bogate lupy dla piekła zbierze, bo ludziom takie prawo będzie odpowiadać, a „i krzyż mu pomoże mało, / Co się biesu obiecało".

Ta parodia dekalogu to nie pierwsza w naszym dramacie kpina „religijna”; tu pełni ona ważną funkcję, bo obnaża „ku przestrodze” czartowski program zwodzenia i kuszenia, a czyni to w lekkiej, ale i zaskakującej nieco nas dzisiaj konwencji. Pamiętać jednak należy, że parodie modlitw znane są już w literaturze średniowiecznej, a pojawiają się potem i w wieku oświeconym (jak w twórczości anonimowych satyryków antytargowickich — Skład konsyliarski czy Dziesięcioro przykazań, trawestuje się też komicznie Biblię — np.: Ksiegii Szczęsnowe Juliana Ursyna Niemcewicza).

${ }^{23}$ Zob. ibidem, s. 107. 
Inny nieco charakter ma scena (część IV) „piekielna” z Historyi o chwalebnym Zmartwychwstaniu Pańskim Mikołaja $z$ Wilkowiecka ${ }^{24}$. Tam sam Chrystus wykreowany jest w sposób groteskowy, szarpie diabły, podtyka im pod nos swą „ufarbowaną krwią choragiew". Krępuje lańcuchami i wpycha do piekła, by spokojnie wyprowadzić stamtąd dusze do zbawienia przeznaczone. Poza przepychankami są też w tej scenie frantowskie komentarze włożone w usta Jezusa. Chcąc wysłać posła do Matki, by przygotować ją na spotkanie ze zmartwychwstałym Synem, nie może wybrać odpowiedniego kandydata. Wszyscy zgłaszający się mają jakieś defekty, choć każdego z nich Biblia opisuje jako szczególnie przez Boga wybranego. I tak: Adam - pierwszy człowiek nie jest godny być posłem, nie dlatego, że jest jednocześnie pierwszym grzesznikiem, lecz dlatego, że zbytnio polubił w raju owoce i jakiś sad po drodze mógłby go zatrzymać; Abel - starotestamentowa prefiguracja Chrystusa - nie nadaje się, bo „zatarżka” $z$ bratem może mu w misji przeszkodzić; Noe - sprawiedliwy wybawiony z odmętów potopu - zbytnio lubi wino, a po przepiciu zasypia, więc poselstwo jego niepewne; Jan Chrzciciel - asceta, wina co prawda nie pija, ale nieodpowiednio jest ubrany („kosmaty” w „wielbłądowej siermiędze”) i Matka by się zlękła takiego posła; jako ostatni zgłasza się „dobry” Łotr, ukrzyżowany wraz z Jezusem, któremu wszak raj został obiecany, ale i on nie spełnia wymagań - ma polamane nogi, co jest najistotniejszą przeszkodą w posłowaniu. Oczywiście zasadniczą funkcją całej części „piekielnej”, jest poszerzenie perspektywy czasowej misterium i przystępnie przeprowadzona edukacja biblijna, ale przydanie tych zdroworozsądkowych, dowcipnych, acz realistycznych, uzasadnień z całą pewnością wzbogacało aspekt dydaktyczny i zapewniało latwiejsze zapamiętanie ważnych postaci biblijnych (bez teologicznych zawikłań i skomplikowanych wywodów) w odruchu ludzkiej solidarności z ich słabościami, a groteskowy Chrystus „wojujący piekło" z pewnością bardziej przemawiał do wyobraźni przeciętnego odbiorcy niż ten z pozostałych, teologicznie ważniejszych, ale nieco nudnych i przegadanych części Historyi... - gdzie zmartwychwstały chwalebnie Pan ukazuje się niewiastom i uczniom.

Wychodząc od "grubych żartów” o podtekście fizjologicznym czy erotycznym, dotarliśmy do tekstów o tematyce religijnej, którym także (przynajmniej miejscami) patronują frant i sowizdrzal - „dobrzy towarzysze”, wypada się więc tu chyba zatrzymać.

Z powyższego przeglądu tekstów literatury tzw. „oficjalnej” wydaje się wynikać, że granice świata frantów i sowizdrzałów można chyba poszerzyć poza utarte tradycją formy semantyczne, bo ich świat to nie tylko obszar szeroko rozumianej literatury sowizdrzalskiej, o której traktują dogłębne studia (choćby Błazeńskie zwierciadto... Sta-

${ }^{24}$ Zob. Mikołaj z Wilkowiecka, Historyja o chwalebnym Zmarturychwstaniu Pańskim, opr. J. Okoń, Wroclaw 1971, s. 47-78. 
nisława Grzeszczuka ${ }^{25}$ ). Ten świat przenika do świata literatury oficjalnej jako przejaw pierwotnej mądrości („inteligencji użytkowej”) czy też zdrowego rozsądku, objawiającego się dosadnym żartem, rubasznym komentarzem czy obsceniczną aluzją do rzeczywistości.

Frantem się jest - przynależąc do „cechu” autorów i postaci, ale frantem się tė̇ w pewnych okolicznościach bywa (autor literatury oficjalnej, sędzia, chłop, kobieta, kapelan, król, Czart, Chrystus...), gdy nie zapomina się ,języka w gębie”, gdy umie się w sytuacji zaskoczenia celnie zripostować a ostrzem humoru, satyry, groteski czy parodii obezwładnić pewnego siebie przeciwnika.

Tak rozumiane frantostwo funkcjonuje na kartach dzieł między innymi: Mikołaj Reja, Jana Kochanowskiego, Wacława Potockiego, Daniela Naborowskiego i wielu innych autorów (nie tylko staropolskich), którzy je doceniają jako przejaw zdroworozsądkowego i zdystansowanego traktowania siebie i innych w ,przypadkach życiowych", ale i sztucznie prowokowanych sytuacjach komicznych.

${ }_{25}$ Zob. S. Grzeszczuk, Błazeńskie zwierciadło. Rzecz o humorystyce sowizdrzalskiej XVI i XVII wieku, Kraków 1994. 